\title{
DEPOSITION OF CARBON FILMS BY DIRECT ION BEAM
}

\author{
Š. Meškinis ${ }^{a}$, S. Tamulevičius ${ }^{a, b}$, and V. Kopustinskas ${ }^{b}$ \\ ${ }^{a}$ Institute of Physical Electronics, Kaunas University of Technology, Savanoriu 271, LT-50131 Kaunas, Lithuania \\ ${ }^{\mathrm{b}}$ Department of Physics, Kaunas University of Technology, K. Donelaičio 73, LT-44029 Kaunas, Lithuania
}

Received 14 July 2004

Dedicated to the 100th anniversary of Professor K. Baršauskas

\begin{abstract}
In this study diamond-like carbon (DLC) films have been grown onto the $\mathrm{Si}(111)$ and steel substrates by direct hydrocarbon (hexane, acetylene) ion beam deposition. Raman spectra of the room temperature deposited carbon films were typical of the hard tetrahedral amorphous carbon films. At 500 and $750 \mathrm{~K}$ temperatures, polymer-like carbon films have been synthesized. Hydrocarbon gas dilution by nitrogen resulted in growth of the more graphitic films. Increase of the deposition temperature resulted in increased internal stress in carbon films deposited from hexane-hydrogen gas mixture. Thin film stress decreased as a result of the hexane-hydrogen mixture dilution by nitrogen. Stress decreased with increase of the nitrogen concentration. It has been revealed that DLC films can be deposited by direct ion beam onto the AISI 316 steel at room temperature. Ion beam nitridation was the best method for increase of adhesion between the DLC and steel substrate.
\end{abstract}

Keywords: hydrogenated amorphous carbon films, clusters, direct ion beam deposition

PACS: $81.05 . U w, 81.15 . J j, 81.65 . C f, 61.46 .+w, 68.55 .-\mathrm{a}$

\section{Introduction}

Diamond like carbon films are isotropic amorphous films with hardness, elastic modulus, and chemical inertness similar to that of the diamond due to the large content of $s p^{3}$ bonds. In many cases these coatings have advantages over polycrystalline diamond films. Structure and properties of the diamond-like carbon films can vary in a wide range [1]. In the case of the hydrogenated amorphous carbon films there are not only the $s p^{2}$ and $s p^{3}$ interatomic bonds, but hydrogencarbon bonds as well. In some cases hydrogen content in a film can reach up to 50 at.\%. These films consist of an amorphous matrix with carbon clusters and crystallites in it. Mechanical properties of $\alpha$-C:H films are defined by $s p^{3}$ bonds, while optical and electrical properties depend upon $s p^{2}$ bonds. Hydrogen can affect mechanical properties and resistance to reactive plasma treatment of the film due to the decreased content of $s p^{3}$ bonds [2-5]. If the content of the $s p^{3}$ bonding in films reaches a high degree (about $80 \%$ ), these films are called tetrahedral amorphous carbon (ta-C) films [1]. Low-density, soft films with large hydrogen fraction in it are called polymer-like carbon films [6].

Diamond and diamond-like carbon coatings have been widely investigated for diverse applications [1].
These coatings can be used as ultrahard, wear resistant, low friction, chemically inert protective coatings, which can be used even in space applications. It is a very promising material for fabrication of the antireflective films and biomedical coatings, cold cathode electron emitters, microelectronic devices, and detectors of ionizing radiation.

A wide array of techniques has been developed for the deposition of those novel carbon materials. High-temperature chemical vapour deposition (CVD) and plasma-enhanced chemical vapour deposition (PECVD) are applied for deposition of the microand nanocrystalline diamond films. Hydrogen-free diamond-like carbon films can be grown by cathodic arc, pulsed laser deposition, ion sputtering. While using plasma enhanced CVD and direct hydrocarbon ion beam deposition, only hydrogenated amorphous carbon films can be grown.

Particularly, direct ion beam deposition using different hydrocarbon ion beams is a versatile tool of formation of many materials in a thin film form [7-15]. Process parameters such as ion beam energy, plasma power, substrate temperature, angle of ion beam incidence, system pressure, gas composition, and flow rate, can be autonomously and precisely controlled over a wide range of process conditions. Films can be de- 
posited both onto the electrically conductive and insulating materials. In such a way ultrahard, wear resistant, low-friction diamond-like coatings can be grown at room temperature [7-11]. Therefore, ion beam deposition of diamond-like carbon (DLC) films is already used for protection of the magnetic media, metal, ceramic, and, especially, glass and plastic. On the other hand, these films typically possess high average stress after growth. Therefore, the problem of intrinsic stress has received much attention [16-23].

It should be noted that growth kinetics and properties of the carbon films are under great influence of the substrates. The substrates can be divided into three groups by the character of interaction between the substrate and the growing film [24]:

- carbide forming materials: $\mathrm{Si}, \mathrm{Ti}, \mathrm{Cr}, \mathrm{W}, \mathrm{SiC}$, etc.;

- strong carbon dissolving materials: $\mathrm{Fe}, \mathrm{Co}, \mathrm{Ni}$, etc.;

- small or non-carbon affinity materials: $\mathrm{Cu}, \mathrm{Au}$.

Particularly, deposition of different carbon films and related materials onto the strong carbon dissolving materials received considerable interest. On the one hand, $\mathrm{Fe}, \mathrm{Co}, \mathrm{Ni}$, and related alloys are used for catalytically assisted deposition of the carbon nanotubes. It is known that $\mathrm{Fe}, \mathrm{Co}$, Ni catalyse the graphite nucleation process and controllable deposition of the carbon nanotubes, and its arrays onto the different substrates can be achieved. On the other hand, use of diamond-like carbon coatings for tribological protection of tools or biomedical implants surface received great attention. In this case hard and wear-protective coatings very often must be deposited onto different steels and other ferrous materials. In this case $\mathrm{Fe}$ as a graphite formation catalyst complicates all the process due to the formation of the soft carbon film and adhesion problems [24-28]. In addition, high carbon dissolving in $\mathrm{Fe}$ and ferrous alloys at high temperatures results in substantially increased diffusion of carbon and carbides from the substrate surface into the bulk of the substrate. Therefore, incubation time of the DLC layer formation is increased. When diamond and diamond-like carbon films are deposited by high-temperature CVD techniques, generation of the thermal stress takes place due to the large mismatch between the thermal expansion coefficients of the coating and the substrate. Therefore, lowtemperature synthesis methods such as deposition by direct hydrocarbon ion beam is under substantial interest.

In this work we summarize regularities of the growth and mechanical properties of carbon films deposited by direct ion beam technique in a wide range of substrate temperatures (293-750 K) emphasizing the role of type of the used substrate and nature of residual stress.

\section{Experimental}

AISI 316 polished steel has been used as a substrate for deposition of the diamond like carbon films for mechanical applications. Commercially available crystalline $n$-Si $\langle 111\rangle$ wafers were used as substrates in most experiments where residual stress in the films was measured.

Carbon films growth was performed using an ion beam etching unit URM3.279.053 equipped with an autonomous electrostatic ion source and substrate resistive heater (deposition temperature can be reached up to $750 \mathrm{~K}$ ).

Amorphous silicon (a-Si), Ti, Cr interlayers on steel substrates were evaporated by electron beam at $10^{-3} \mathrm{~Pa}$ base pressure at a substrate temperature of $100^{\circ} \mathrm{C}$. Thickness of the evaporated layer was controlled by using a quartz resonator.

For the studies of the nitrogen doping effects, through the other channel the $\mathrm{N}_{2}$ gas flowed only. The $\mathrm{C}_{6} \mathrm{H}_{14}+\mathrm{H}_{2}$ vapour or acetylene gas $\left(\mathrm{C}_{2} \mathrm{H}_{2}\right)$ was mixed with the $\mathrm{N}_{2}$ gas before reaching the ion source. The hydrocarbon gas and $\mathrm{N}_{2}$ vapour flux was regulated by a needle valve. Concentration of $\mathrm{N}_{2}$ in the $\mathrm{C}_{6} \mathrm{H}_{14}+\mathrm{H}_{2}+\mathrm{N}_{2}$ gas mixture was changed from 5 to $40 \%$. Thickness of the carbon films varied in the range of $200-1000 \mathrm{~nm}$.

Conditions of the deposition process are shortly presented in Table 1.

As one of the low-cost methods for determining residual film stress, an optically levered laser technique was used to measure a radius of substrate curvature induced by a deposited film. Stoney's equation for a film, whose thickness is small compared to the substrate

Table 1. Conditions of the carbon films deposition process.

\begin{tabular}{lc}
\hline Substrate & (a) $n$-Si $\langle 111\rangle$ \\
& (b) $n$-Si $\langle 111\rangle$ coated with \\
the $300 \mathrm{~nm}$ thick $\mathrm{SiO}_{2}$ \\
(c) $n$-Si $\langle 111\rangle+\mathrm{SiO}_{2}+\mathrm{Ni}$ \\
(d) polished AISI 316 steel \\
(ion beam treated or with \\
a-Si, $\mathrm{Ti}, \mathrm{Cr}$ interlayers) \\
$\mathrm{C}_{6} \mathrm{H}_{14}+\mathrm{H}_{2}, \mathrm{C}_{2} \mathrm{H}_{2}, \mathrm{~N}_{2}$ \\
$2 \cdot 10^{-2} \mathrm{~Pa}$ \\
$0-40 \%$ \\
Reagents \\
$\begin{array}{l}\mathrm{N}_{2} \text { content } \\
\text { Ion beam energy } \\
\text { Ion beam current density }\end{array}$ \\
$0.12 \pm 0.01 \mathrm{~mA} / \mathrm{cm}^{2}$ \\
\hline
\end{tabular}


thickness, relates average stress in the film and variation of the curvature of the film-substrate system [29]:

$$
\sigma_{\mathrm{f}}=\frac{1}{6} \frac{E_{\mathrm{s}} h_{\mathrm{s}}^{2}}{(1-\nu) h_{\mathrm{f}}}\left(\frac{1}{R_{2}}-\frac{1}{R_{1}}\right),
$$

where $E_{\mathrm{s}}$ is the Young's modulus of the substrate, $h_{\mathrm{s}}$ is the thickness of the substrate, $\nu$ is the Poisson's ratio of the substrate, $h_{\mathrm{f}}$ is the film thickness, $R_{2}$ and $R_{1}$ are the radii of the substrate after and before thin film deposition, respectively.

In the present study the prism interferometer including a He-Ne laser (wavelength $632.8 \mathrm{~nm}$, output power $10 \mathrm{~mW}$ ) was used to measure the curvature of the substrate [29]. The sensitivity of the cantilever technique in the strain measurements can reach $10^{-6}$ and this fact allows applying this method for control of the nucleation and coalescence of thin films that can be provided both in situ or ex situ. Using the silicon substrate (with thickness $250 \mu \mathrm{m}$ ) allowed providing measurements of the residual stress with accuracy not lower than $10 \%$.

Applying extra thermal heating of the formed structure within a small temperature region (tens of degrees), one can differentiate between the intrinsic stress (that is constant within a narrow region of temperatures) and change of thermal stress that is a linear function of the applied temperature [30]:

$$
\mathrm{d} \sigma_{\mathrm{th}}=E_{\mathrm{f}}\left(\alpha_{\mathrm{s}}-\alpha_{\mathrm{f}}\right) \mathrm{d} T,
$$

where $\mathrm{d} \sigma_{\mathrm{th}}$ is the change of thermal stress (due to extra heating), $\alpha_{\mathrm{S}}$ and $\alpha_{\mathrm{f}}$ are the thermal expansion coefficients of the substrate and thin film, and $\mathrm{d} T$ is the incremental temperature.

Knowing the rate of change $\mathrm{d} \sigma / \mathrm{d} T$ (due to extra heating), one can define the thermal stress component of the residual stress in thin films (assuming that linear dependence is valid for the investigated region of temperatures):

$$
\sigma_{\mathrm{th}}=\frac{\mathrm{d} \sigma}{\mathrm{d} T}\left(T_{2}-T_{1}\right),
$$

where $T_{1}$ is the deposition temperature and $T_{2}$ is the room temperature.

These measurements were performed using a Michelson interferometer [29] supplied with the noncontact heater and a temperature control system mounted to the thermostabilized vacuum chamber.

Thin film structure was evaluated using the Raman spectroscopy. He-Ne laser (wavelength $632.8 \mathrm{~nm}$, output power $15 \mathrm{~mW}$ ) was used. Light was analysed with an $f / 5.3$ double monochromator with 1200 lines $/ \mathrm{mm}$ gratings and detected by a photomultiplier (cooled to $283 \mathrm{~K}$ ) and a photon counting system.
Adhesion between the steel substrate and deposited diamond-like carbon film was evaluated using scratch testing.

\section{Experimental results and discussion}

\subsection{Structure of the ion beam deposited carbon films}

Raman spectra of the samples deposited from the hexane-hydrogen mixture are presented in Fig. 1. In the case of the films deposited at room and $400 \mathrm{~K}$ temperature, Raman spectra are typical of diamond-like carbon films [1]. A wide and very intensive $I_{\mathrm{D}}$ peak at $\sim 1300 \mathrm{~cm}^{-1}$ can be seen in the case of the thin films deposited directly onto the $\mathrm{SiO}_{2}$ layer at $473 \mathrm{~K}$ and $750 \mathrm{~K}$ temperature. It must be mentioned that similar approach of the Raman spectra has been reported for polymer-like carbon films deposited by plasma enhanced CVD without the negative substrate bias, while negative substrate bias resulted in formation of the diamond like films [6]. A weak $I_{\text {G }}$ peak at $1577 \mathrm{~cm}^{-1}$ can be seen in the case of the film deposited at $750 \mathrm{~K}$ temperature as well.

Doping effect dependence of $\alpha-\mathrm{CN}_{x}: \mathrm{H}$ films structure on the $\mathrm{N}_{2}$ concentration can be seen in Fig. 2 .

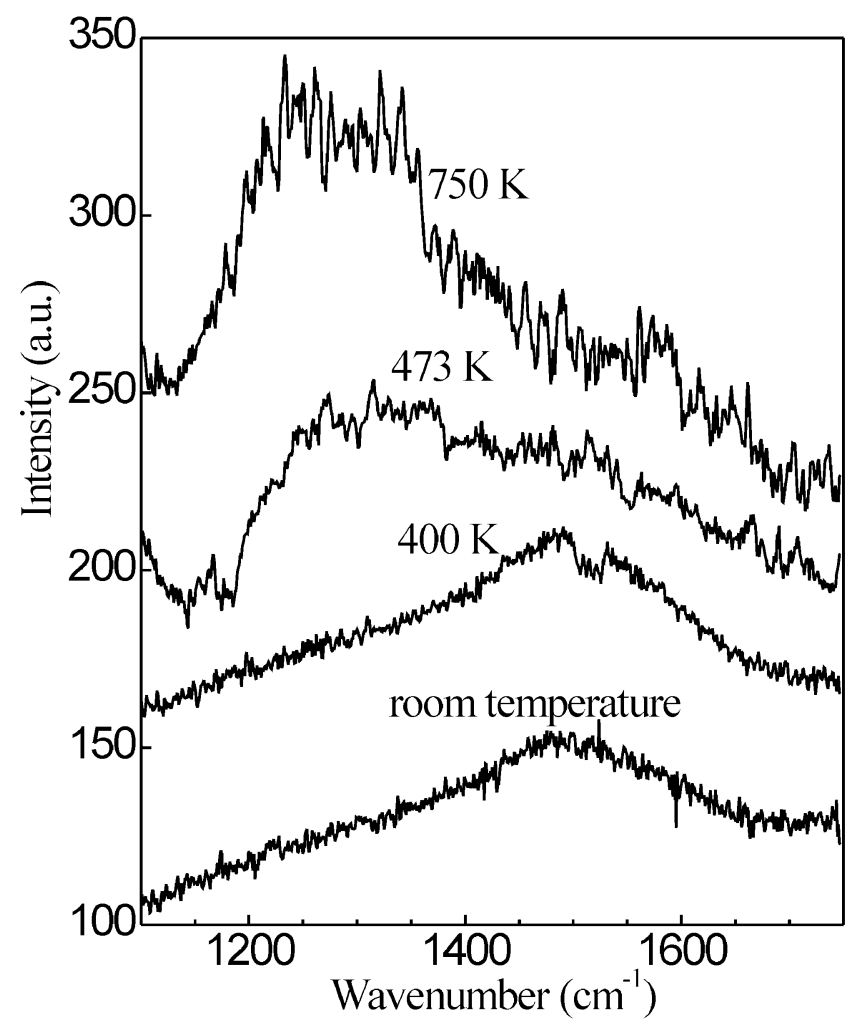

Fig. 1. Raman spectra of $\alpha$-C:H films deposited from hexanehydrogen gas mixture on the silicon substrate at different temperatures. 


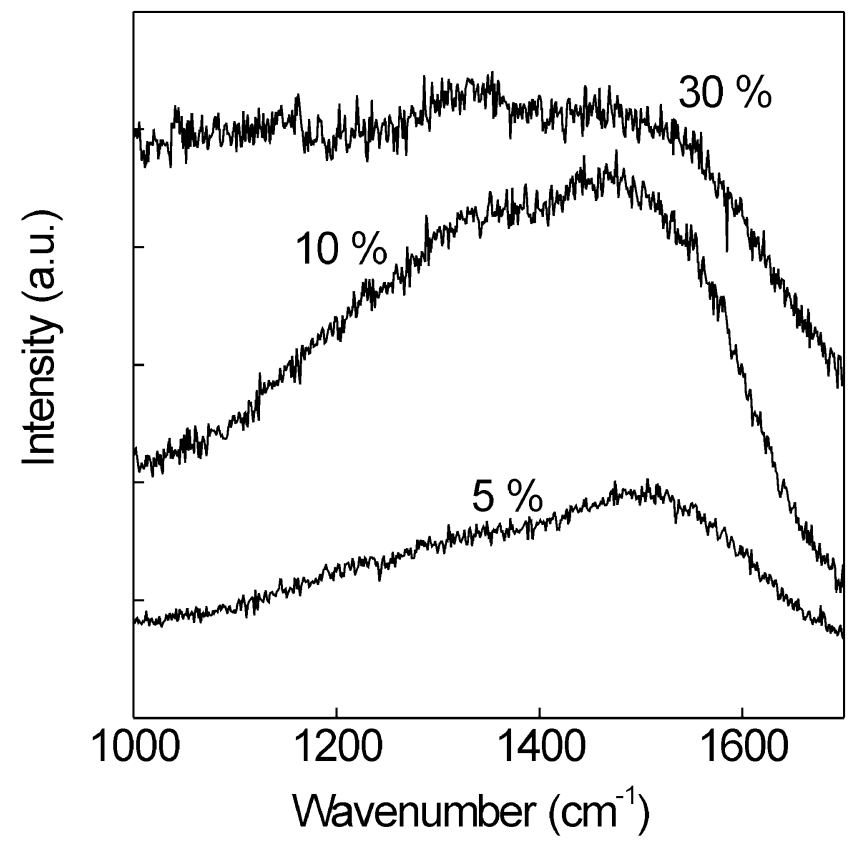

Fig. 2. Raman spectra of $\alpha-\mathrm{CN}_{x}: \mathrm{H}$ films deposited at different $\mathrm{N}_{2}$ concentrations $\left(\mathrm{C}_{6} \mathrm{H}_{14}+\mathrm{H}_{2}\right.$ gas mixture has been used as a source of hydrocarbons, deposition temperature $293 \mathrm{~K}$ ).

The wide peak at the $1520 \mathrm{~cm}^{-1}$ dominated in all investigated cases. This peak shows the presence of the graphite phase in the film ( $s p^{2}$ bond). The wide peak at $1350 \mathrm{~cm}^{-1}$ wavelength indicates level of the disorder of the hybridized orbitals binding angles in $s p^{3}$ carbon bonds matrix. It can be seen that disorder in $s p^{3}$ atom bond matrix increases (the $s p^{3} / s p^{2}$ ratio decreases) when $\mathrm{N}_{2}$ concentration increases. As a result, films become more graphite-like. These results are similar to those of $\alpha-\mathrm{CN}_{x}: \mathrm{H}$ films deposited by reactive sputtering [31]. However, for $\alpha-\mathrm{CN}_{x}: \mathrm{H}$ films deposited by CVD, there were no changes in Raman spectra as the amount of nitrogen is increased up to $20 \%$ [32].

One can see that the structure of the carbon films deposited directly onto $\mathrm{Si}(111)$ changed from diamondlike carbon to polymer-like carbon already at $473 \mathrm{~K}$ temperature. At higher deposition temperatures the structure of the polymer-like carbon films evolved towards more graphitic films.

\subsection{Mechanical properties of the ion beam deposited carbon films}

Application of thin films is strongly influenced by the mechanical properties and one critical issue especially important in mechanical applications is the level of the residual stress in the films. In this section we present analysis of the residual stress in the direct ion beam current deposited carbon films. It was revealed

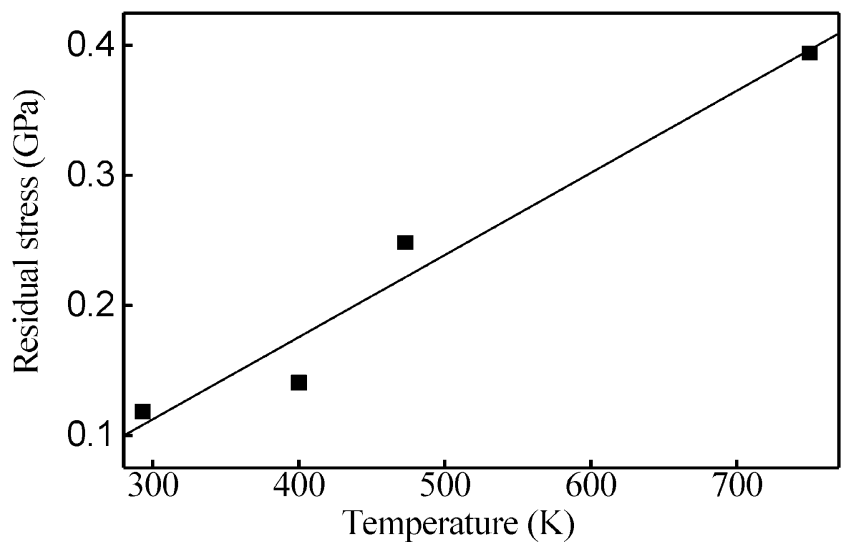

Fig. 3. The dependence of the residual stress of carbon films on the deposition temperature.

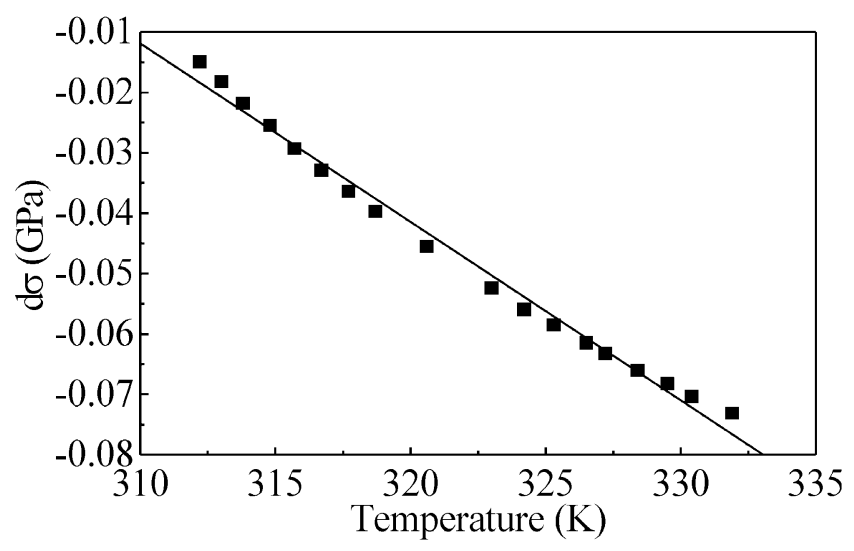

Fig. 4. Stress changes with the temperature of the carbon film deposited at $400 \mathrm{~K}$ temperature due to extra thermal heating after the deposition.

that tensile stress prevails in all the films for the investigated range of temperatures. Dependence of the residual stress in $\alpha-\mathrm{C}: \mathrm{H}$ thin films on deposition temperature is presented in Fig. 3. The linear stress increase with the deposition temperature can be seen. The stress increases from $0.118 \mathrm{GPa}$ to nearly $0.4 \mathrm{GPa}$, when the deposition temperature increases from room to $750 \mathrm{~K}$.

While applying extra heating (after the deposition) to the samples from room temperature up to $333 \mathrm{~K}$, the decrease of the stress by 60-70 MPa was observed for all the investigated samples. The typical dependence of the stress changes with the temperature due to extra heating for the film deposited at $400 \mathrm{~K}$ (film thickness $400 \mathrm{~nm}$ ) is presented in Fig. 4. Extrapolating the dependence of Fig. 4 by a line, the rate of change of the stress was determined as $\mathrm{d} \sigma / \mathrm{d} T=-2.9 \mathrm{MPa} / \mathrm{deg}$. Evaluation of the tensile thermal stress in accordance with Eq. (3) gives $\sigma_{\text {th }}=0.32 \mathrm{GPa}$ for the films de- 


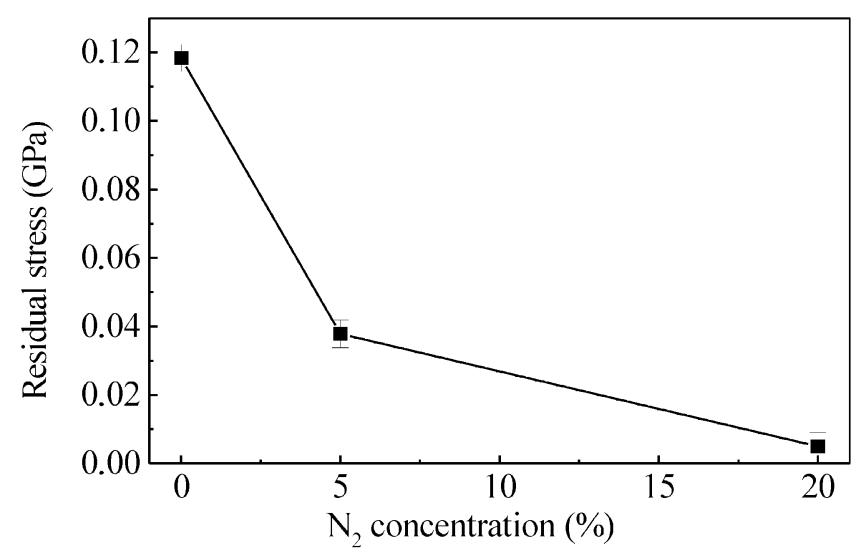

Fig. 5. The dependence of the residual stress of $\alpha-\mathrm{CN}_{x}: \mathrm{H}$ films deposited at room temperature from $\mathrm{C}_{6} \mathrm{H}_{14}+\mathrm{H}_{2}$ gas mixture on the $\mathrm{N}_{2}$ gas content in the flux.

posited at $400 \mathrm{~K}$, i. e. this value exceeds the total residual stress $(0.14 \mathrm{GPa})$ as presented in Fig. 3.

Even more controversial results were obtained for the polymer-like carbon film deposited at $750 \mathrm{~K}$ temperature. In this case $\mathrm{d} \sigma / \mathrm{d} T=-11.9 \mathrm{MPa} / \mathrm{deg}$ and tensile thermal stress as high as $5.355 \mathrm{GPa}$ was obtained in accordance to Eq. (3).

Despite that stress tendency due to extra heating corresponds to the experimentally known values of thermal expansion coefficients, absolute values of the stress (and thermal stress calculated according to Eq. (3)) illustrate that stress relaxation processes during deposition take place. The stress reduction due to relaxation processes according to our results is higher for the films deposited at high temperatures where polymer-like carbon films are produced. One can understand that during the cooling of the substrate-film system from deposition to room temperature, thermal stress exceeds the limits of the elastic deformation of the thin film and stress relaxation due to the plastic deformation takes place. These considerations are in good agreement with the Raman scattering spectra (Fig. 1).

Introduction of nitrogen to the growing film during deposition (doping by nitrogen) resulted in the decrease of the internal stress of $\alpha-\mathrm{C}: \mathrm{H}$ films (Fig. 5).

On the other hand, doping by nitrogen leads to decrease of wear resistance of the films. From Fig. 6 it can be seen that $10 \%$ nitrogen doping resulted only in slight decrease of the wear resistance. One can see as well that substantial worsening of the wear resistance takes place only at $10 \%$ of nitrogen in the total gas flow. It means that nitrogen can be used for reduction of the internal stress of carbon films applied as tribological coatings.

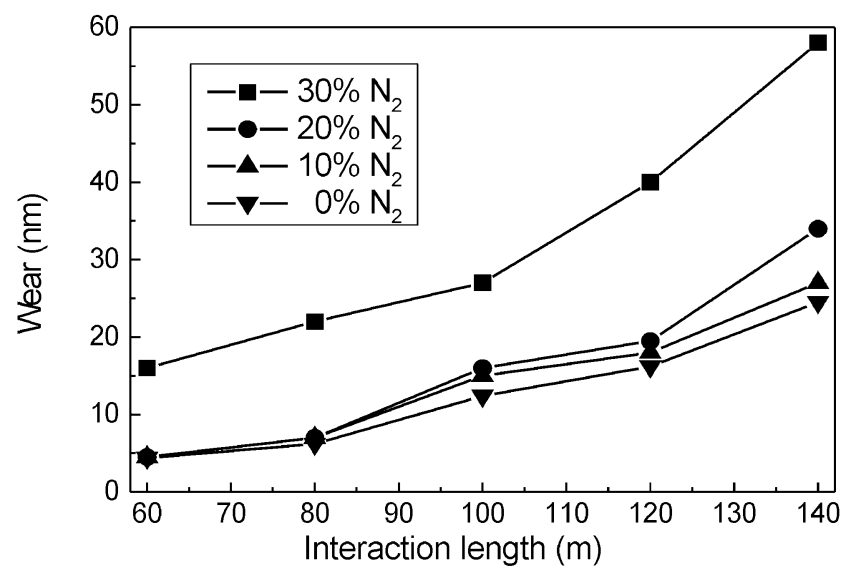

Fig. 6. The decrease of coating thickness (wear) as a function of the interaction length for coatings produced at different $\mathrm{N}_{2}$ concentrations (load $p=0.88 \cdot 10^{3} \mathrm{~N} / \mathrm{m}^{2}=$ const, $\mathrm{C}_{6} \mathrm{H}_{14}+\mathrm{H}_{2}$ gas mixture has been used as a source of hydrocarbons).

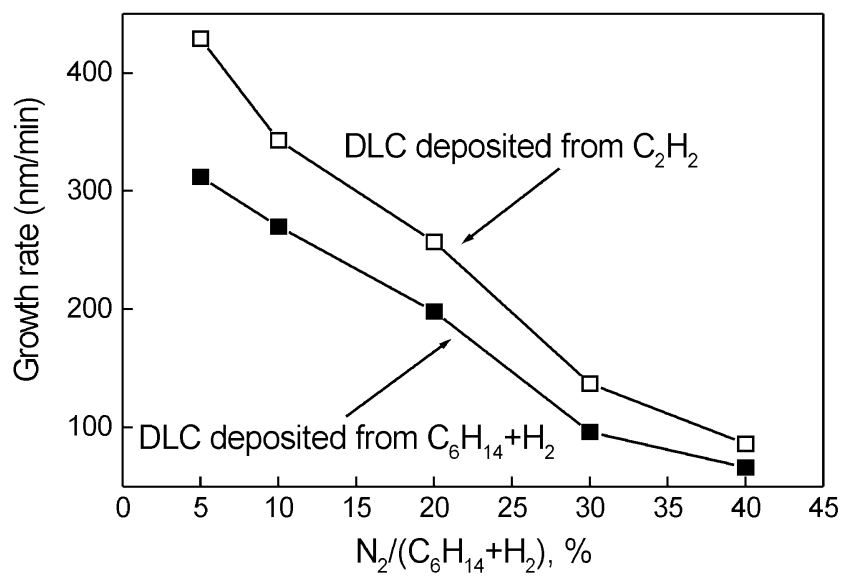

Fig. 7. Dependence of the $\alpha-\mathrm{CN}_{x}: \mathrm{H}$ film growth rate on the $\mathrm{N}_{2}$ gas concentration.

Dilution of both hexane-hydrogen gas mixture and acetylene gas by nitrogen resulted in decreased growth rate (Fig. 7). Similar effects of $\mathrm{N}_{2}$ concentration on carbon nitride film growth rate have been observed for coatings deposited both by rf and electron cyclotron resonance plasma enhanced CVD [33,34]. This experimental dependence can be explained as a result of decrease of the concentration of reagents in the ion source - dilution of $\mathrm{C}_{6} \mathrm{H}_{14}+\mathrm{H}_{2}$ gas mixture by $\mathrm{N}_{2}$ gas. However, other authors explained this phenomenon as well by increased sputtering of the growing films by $\mathrm{N}_{2}^{+}$ions [34]. On the other hand, it must be mentioned that for films deposited by CVD or DC sputtering, the increase of the growth rate with $\mathrm{N}_{2}$ concentration has been observed $[32,35]$. This fact supports suggestion about the influence of the increased sputtering of the films 
by $\mathrm{N}_{2}^{+}$ions on the growth rate of carbon nitride films.

Analysing the variety of experimental results of other researchers, many controversial facts can be found. For example, compressive stress has been observed in $[16-18,36]$. Such discrepancy can be explained by the use of lower ion energies during deposition. Stress level decrease about 5 times with the energy increase from $100 \mathrm{eV}$ to $800 \mathrm{eV}$ was reported in [16]. Similar approach was observed for the bias assisted plasma CVD deposited DLC films [19]. In comparison with the present study, diamond-like films deposited at lower energies were much more stressed $[17,18,36]$, while the absolute value of the stress of polymer-like carbon film was close to our study (0.1 GPa [6] and $0.7 \mathrm{GPa}[36]$ versus $0.4 \mathrm{GPa}$, respectively). Main sources of tensile stress and its relaxation $[22,23,36]$ are in good agreement with our results, where relaxation of the tensile stress was found to be essential for the polymer-like carbon films formed at high temperatures and films produced with the nitrogen doping. In addition, absolute values of the tensile stress were similar to the ones obtained in our study $(0.2-0.4 \mathrm{GPa})$. Tensile stress similarly to our results was reported for the bias assisted DC plasma DLC coatings [37] as well. Therefore, decrease of the tensile internal stress with the increased nitrogen doping can be explained by increased amount of a non-diamond phase [7], that is beneficial to the relaxation of intrinsic tensile stress [23] and by appearance of the compressive stress due to non-diamond carbon impurities at the grain boundaries [22].

\subsection{Deposition of DLC on steel substrates}

Deposition conditions were similar to the ones in the case of silicon substrates (Table 1). It should be noted that in these experiments steel surface roughness plays a key role in defining mechanical properties and stability of the coatings. Deposition of the DLC on rough surface brings to the poor adhesion that can not be improved either by extra ion irradiation $\left(\mathrm{Ar}^{+}, \mathrm{N}^{+}\right)$of substrate either formation by interlayer. All these coatings have peeled, and the only efficient way to produce well adherent DLC was the mechanical polishing of the steel substrate.

Steel surface mechanical abrasion and polishing substantially improved adhesion of the coating. Four methods of the adhesion improvement were tested deposition of a-Si or Ti interlayer, steel surface treatment by $\mathrm{Ar}^{+}$ion beam, and steel surface treatment by

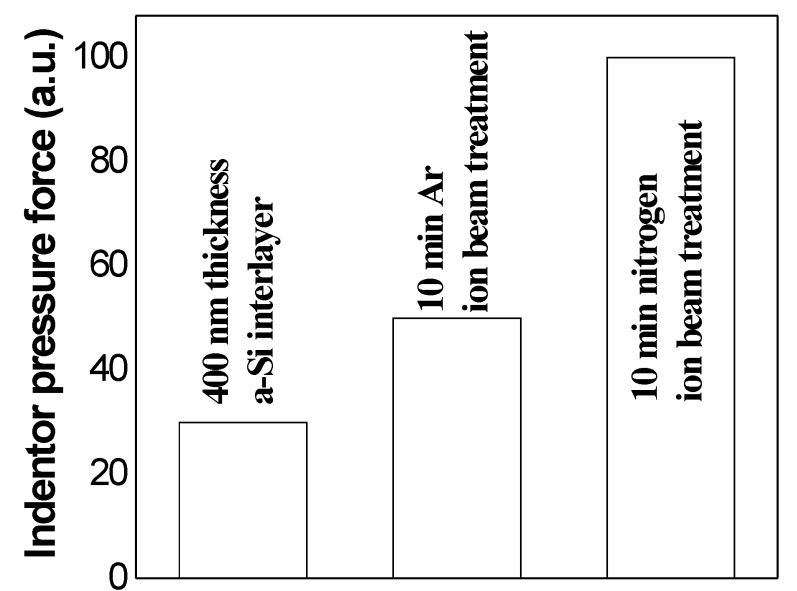

Fig. 8. Adhesion of DLC deposited from acethylene gas on the AISI 316 steel substrate versus different types of surface preparation. Thickness of DLC in all cases was $800 \mathrm{~nm}$.

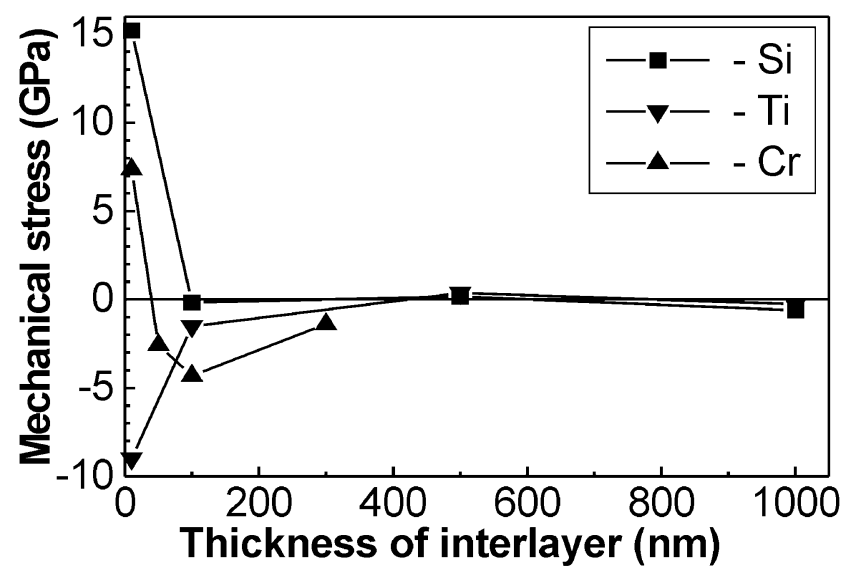

Fig. 9. Mechanical stress in thin Ti, Cr, a-Si interlayers deposited on the $\mathrm{Si}(111)$ substrate.

nitrogen ion beam. It can be seen in Fig. 8 that the best adhesion was between the nitrogen ion treated steel surface and a diamond-like coating. The $400 \mathrm{~nm}$ thickness silicon interlayer was the least effective measure, while deposition of $100 \mathrm{~nm}$ thickness Ti interlayer before diamond-like carbon film synthesis substantially worsened the adhesion. Peeling of the carbon coating took place. Increase of the Ti interlayer thickness up to $1000 \mathrm{~nm}$ Ti resulted in even larger disimprovement.

To reveal influence of internal stress in thin DLC films and used interlayers additional experiments were performed. In this case interlayers and diamond-like carbon films were deposited onto the $\mathrm{Si}\langle 111\rangle$ substrates. Analysis of the stress in $\mathrm{Ti}, \mathrm{Cr}, \mathrm{Si}$ interlayers revealed that the highest stress level is in thin (10 nm thickness) interlayers (Fig. 9). Increase of the interlayer thickness resulted in decrease of the stress. 
Table 2. Reference data on use of Si interlayers for improvement of the adhesion between the diamond like carbon film and

\begin{tabular}{|c|c|c|c|c|c|c|}
\hline $\begin{array}{l}\text { Refer- } \\
\text { ence }\end{array}$ & $\begin{array}{l}\text { DLC synthesis } \\
\text { method }\end{array}$ & $\begin{array}{l}\text { Deposition } \\
\text { temperature }\end{array}$ & $\begin{array}{l}\text { Thickness } \\
\text { of DLC }\end{array}$ & $\begin{array}{c}\text { Si interlayer } \\
\text { deposition method }\end{array}$ & $\begin{array}{l}\text { Thickness of } \\
\text { Si interlayer }\end{array}$ & Comments \\
\hline$[48]$ & $\begin{array}{c}\text { RF plasma } \\
\text { enhanced CVD }\end{array}$ & $140^{\circ} \mathrm{C}$ & $1 \mu \mathrm{m}$ & $\begin{array}{l}\text { Magnetron } \\
\text { sputtering }\end{array}$ & $50 \mathrm{~nm}$ & \\
\hline$[45]$ & $\begin{array}{l}\text { MW plasma } \\
\text { enhanced CVD }\end{array}$ & $900^{\circ} \mathrm{C}$ & $4-6 \mu \mathrm{m}$ & $?$ & $\begin{array}{l}40 \mathrm{~nm} \\
\ll 40 \mathrm{~nm}\end{array}$ & $\begin{array}{l}\text { Better adhesion on } \\
\text { the thinner interlayer }\end{array}$ \\
\hline [50] & $\begin{array}{l}\text { MW plasma } \\
\text { enhanced CVD }\end{array}$ & $600{ }^{\circ} \mathrm{C}$ & $?$ & $\begin{array}{c}\text { Vacuum } \\
\text { evaporation }\end{array}$ & $20 \mathrm{~nm}$ & \\
\hline [49] & $\begin{array}{c}\text { RF plasma } \\
\text { enhanced CVD }\end{array}$ & $200^{\circ} \mathrm{C}$ & $3-8 \mu \mathrm{m}$ & $?$ & $300 \mathrm{~nm}$ & \\
\hline [46] & $\begin{array}{c}\text { RF plasma } \\
\text { enhanced CVD }\end{array}$ & $?$ & $2 \mu \mathrm{m}$ & RF plasma & $\begin{array}{c}38 \mathrm{~nm} \\
150 \mathrm{~nm}\end{array}$ & $\begin{array}{l}\text { Adhesion of the DLC film } \\
\text { deposited on the } 38 \mathrm{~nm} \text { thick } \\
\text { interlayer better than that of } \\
\text { the film deposited on the } \\
150 \mathrm{~nm} \text { thick interlayer }\end{array}$ \\
\hline [47] & $\begin{array}{l}\text { Ion beam } \\
\text { synthesis }\end{array}$ & $30^{\circ} \mathrm{C}$ & $1.7 \mu \mathrm{m}$ & $\begin{array}{l}\text { Sputter- } \\
\text { deposition }\end{array}$ & $100 \mathrm{~nm}$ & \\
\hline
\end{tabular}

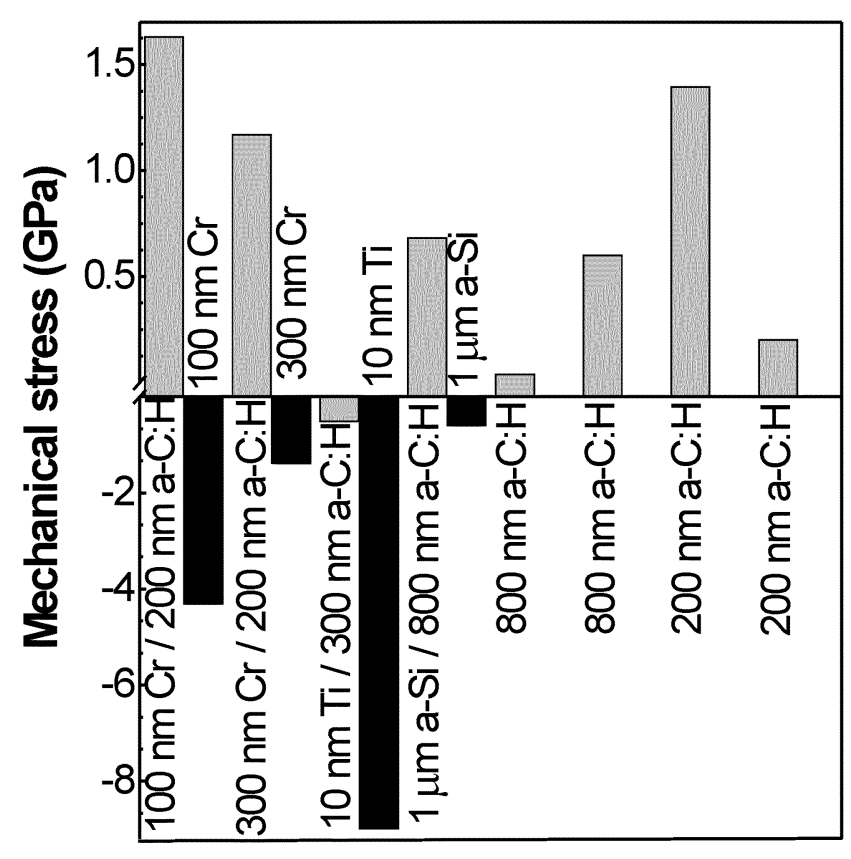

Fig. 10. Mechanical stress in DLC films deposited on Ti, Cr, a-Si interlayers of different thickness. $\mathrm{Si}\langle 111\rangle$ was used as a substrate.

One can see that use of the layers with thickness $200 \mathrm{~nm}$ and higher allowed the stress level to be minimized.

$200 \mathrm{~nm}$ thick DLC coatings were deposited on the Ti and $\mathrm{Cr}$ interlayers (Fig. 10). $800 \mathrm{~nm}$ thick DLC coatings were deposited onto the a-Si interlayer due to the relative effectiveness of this interlayer.

It is hard to directly compare data on deposition of DLC films onto the a-Si interlayer with data on deposition of DLC films onto the $\mathrm{Cr}$ interlayer due to the different thickness of the deposited DLC films in these cases. However, internal stress in $800 \mathrm{~nm}$ thick DLC film deposited onto the $1000 \mathrm{~nm}$ thick a-Si interlayer is lower than internal stress in $200 \mathrm{~nm}$ thick DLC films deposited on 100 and $300 \mathrm{~nm}$ thick $\mathrm{Cr}$ interlayers.

From the first look, better adhesion between DLC and $\mathrm{Cr}$ in comparison with adhesion between the DLC and Ti contradicts the results referred by other authors $[24,28,38]$. However, it must be mentioned that in all cited studies DLC has been deposited by PECVD at high $\left(700-800^{\circ} \mathrm{C}\right)$ temperature, while in our study synthesis was performed at room temperature. Therefore, despite higher TiC bonding energy in comparison with $\mathrm{Cr}-\mathrm{C}$ bond [38], perhaps there is no enough energy at room temperature for TiC formation. It can be mentioned that in all studies where deposition of the DLC films on a Ti interlayer or Ti substrate was performed, the synthesis temperature was $500-550{ }^{\circ} \mathrm{C}$ or more [39-41]. At room temperature DLC films were deposited on the $\mathrm{TiC}$ [42] interlayer or nitrogen doping was used [43]. In the case of the DLC film deposition on the $\mathrm{Cr}$ interlayer, low-temperature synthesis of the diamond like carbon films was performed only applying $\mathrm{W}$ doping [44].

It can be mentioned as well that in $[45,46]$ more adherent DLC films were deposited using a thinner $\mathrm{Si}$ interlayer contrary to the results of the present study. Table 2 summarizes the main results of other researchers on the analysis of $\mathrm{Si}$ interlayer influence on the properties of DLC. However, one can see that in the cited works diamond-like carbon films were syn- 
thesized at high temperature, while in the case of the low-temperature deposition in different studies $\mathrm{Si}$ interlayers of different thickness were used [47-49].

\section{Conclusions}

In conclusion, Raman spectra of the carbon films deposited from direct ion beam onto the $\mathrm{Si}(111)$ substrate at room and $400 \mathrm{~K}$ temperature are typical of diamondlike carbon films. Increase of the deposition temperature results in formation of the polymer-like carbon films.

Internal stress of the films increases with the deposition temperature from 0.114 to $0.52 \mathrm{GPa}$ illustrating importance of the thermal stress component. Absolute values of the stress show that stress relaxation processes take place. The stress reduction is higher for the films deposited at high temperatures where polymerlike carbon films are produced. During the cooling of the substrate-film system from the deposition to room temperature, thermal stress exceeds the limits of the elastic deformation of the thin film and stress relaxation due to the plastic deformation takes place. Nitrogen doping resulted in the decreased stress level. Formation of the more graphitic coating or polymer-like carbon phase contributes to the thermal stress relaxation.

Diamond-like carbon films can be deposited onto the steel substrate at room temperature using direct ion beam deposition. Ion beam nitridation is the most efficient method to increase adhesion between the DLC and steel substrate.

\section{Acknowledgements}

Support of the Lithuanian Science and Education Foundation is acknowledged. Support in the frame of the project "Nano-structured functional coatings for optical and lubricating applications" of the NATO Science Programme - Cooperative Science and Technology is acknowledged as well. Authors would like acknowledge Dr. G. Niaura (Institute of Chemistry) for help in measurements of Raman scattering spectra.

\section{References}

[1] J. Robertson, Diamond-like amorphous carbon, Mater. Sci. Eng. R 37, 129-281 (2002).

[2] T. Miyamura, O. Yoshida et al., Effect of surface treatments on adsorption and tribology of the diamond-like carbon layer for metal-evaporated tape, Jpn. J. Appl. Phys. 37, 6153-6156 (1998).

[3] A.M. Baranov, Planarization of substrate surface by means of ultrathin the diamond-like carbon film, Surf. Coat. Technol. 102, 154-158 (1998).

[4] H. Shiomi, Reactive ion etching of diamond in $\mathrm{O}_{2}$ and $\mathrm{CF}_{4}$ plasma, Jpn. J. Appl. Phys. 36, 7745-7748 (1997).

[5] O.S. Panwar, D. Sarangi, S. Kumar, P.N. Dixit, and R. Bhattacharyya, Diamond-like carbon films grown using a saddle field source, J. Vac. Sci. Technol. A 13, 2519-2524 (1995).

[6] X.T. Zhou, S.T. Lee, I. Bello, A.C. Cheung, D.S. Chiu, Y.W. Lam, C.S. Lee, K.M. Leung, and X.M. He, Physical properties of a-C:H films prepared by electron cyclotron resonance microwave plasma chemical vapor deposition, Mater. Sci. Eng. B 77, 229-234 (2000).

[7] V. Kopustinskas, Š. Meškinis, V. Grigaliūnas, S. Tamulevičius, M. Pucèta, G. Niaura, and R. Tomašiūnas, Ion beam synthesis of a-CN $\mathrm{CN}_{x}: \mathrm{H}$ films, Surf. Coat. Technol. 151-152, 180-183 (2002).

[8] R.L.C. Wu, W. Lanter, J. Wrbanek, and C. DeJoseph, Large-area surface treatment by ion beam technique, Surf. Coating Technol. 140, 35-43 (2001).

[9] K. Yamamoto, K. Wazumi, T. Watanabe, Y. Koga, and S. Iijima, Tribological properties of diamond-like carbon films prepared by mass-separated ion beam deposition, Diamond Relat. Mater. 11, 1130-1134 (2002).

[10] W.W. Scott, B. Bhushana, and A.V. Lakshmikumaran, Ultrathin diamond-like carbon coatings used for reduction of pole tip recession in magnetic tape heads, J. Appl. Phys. 87, 6182-6184 (2000).

[11] H. Hofsass, C. Ronning, and H. Feldermann, Film growth using mass-separated ion beams, in: Application of Accelerators in Research and Industry 16th International Conference, eds. J.L. Duggan and I.L. Morgan (American Institute of Physics, 2001) pp. 947-950.

[12] V. Kopustinskas, S. Meskinis, S. Tamulevicius, G. Niaura, A. Guobiene, and V. Grigaliunas, Direct ion beam deposited carbon films and clusters, Vacuum 72, 193-198 (2003).

[13] V. Kopustinskas, J. Margelevičius, Š. Meškinis, and V. Grigaliūnas, Diamond-like carbon films synthesis by ion beam, Materials Science (Medžiagotyra) 1, 3336 (1998).

[14] S. Tamulevicius, V. Kopustinskas, S. Meskinis, and L. Augulis, Mechanical properties of ion beam deposited carbon films (in press, uncorrected proof at http: //www.sciencedirect. com).

[15] S. Tamulevičius, L. Augulis, Š. Meškinis, and V. Grigaliūnas, Mechanical properties of carbon thin films, in: NATO Science Series Volume: Frontiers in Molecular-Scale Science and Technology of Nanocarbon, Nanosilicon and Biopolymer Integrated Nanosystems, eds. P. Scharff and E. Buzaneva (in press). 
[16] H. Hofsass, C. Ronning, and H. Feldermann, Film growth using mass-separated ion beams, in: Application of Accelerators in Research and Industry 16th International Conference, eds. J.L. Duggan and I.L. Morgan (American Institute of Physics, 2001) pp. 947-950.

[17] B. Druz, I. Zaritskiy, J. Hoehn, V.I. Polyakov, A.I. Rukovishnikov, and V. Novotny, Direct ion beam deposition of hard $30 \mathrm{GPa}$ diamond-like films from RF inductively coupled plasma source, Diamond Relat. Mater. 10, 931-936 (2001).

[18] C. Lenardi, M.A. Baker, V. Briois, L. Nobili, P. Piseri, and W. Gissler, Properties of amorphous a-CH(:N) films synthesized by direct ion beam deposition and plasma-assisted chemical vapour deposition, Diamond Relat. Mater. 8, 595-600 (1999).

[19] N. Maýtre, Th. Girardeau, S. Camelio, A. Barranco, D. Vouagner, and E. Breelle, Effects of negative low self-bias on hydrogenated amorphous carbon films deposited by PECVD technique, Diamond Relat. Mater. 12, 988-992 (2003).

[20] D. Sheeja, B.K. Tay, K.W. Leong, and C.H. Lee, Effect of film thickness on the stress and adhesion of diamond-like carbon coatings, Diamond Relat. Mater. 11, 1643-1647 (2002).

[21] A.C. Ferrari, S.E. Rodil, J. Robertson, and W.I. Milne, Is stress necessary to stabilise $s p$ bonding in diamondlike carbon?, Diamond Relat. Mater. 11, 994-999 (2002).

[22] O. Durand, R. Bisaro, C.J. Brierley, P. Galtier, G.R. Kennedy, J.K. Kruger, and J. Olivier, Residual stresses in chemical vapor deposition free-standing diamond films by X-ray diffraction analyses, Mater. Sci. Eng. A 228, 217-222 (2000).

[23] N.G. Shang, C.S. Lee, Z.D. Lin, I. Bello, and S.T. Lee, Intrinsic stress evolution in diamond films prepared in a $\mathrm{CH}_{4} \mathrm{H}_{2} \mathrm{NH}_{3}$ hot filament chemical vapor deposition system, Diamond Relat. Mater. 9, 1388-1392 (2000).

[24] N. Ali, Qi Hua Fan, J. Gracio, E. Pereira, and W. Ahmed, A comparison study of diamond adhesion on ductile metals, Thin Solid Films 377-378, 193-197 (2000).

[25] D.J. Li, F.Z. Ui, and H.Q. Gu, Studies of diamond-like carbon films coated on PMMA by ion beam assisted deposition, Appl. Surf. Sci. 137, 30-37 (1999).

[26] A. Fayer, O. Glozman, and A. Hoffman, Deposition of continuous and well adhering diamond steel, Appl. Phys. Lett. 67, 2299-2301 (1995).

[27] J.G. Buijnsters, P. Shankar, P. Gopalakrishnan, W.J.P. van Enckevort, J.J. Schermer, S.S. Ramakrishnan, and J.J. ter Meulen, Diffusion-modified boride interlayers for chemical vapour deposition of low-residual-stress diamond films on steel substrates, Thin Solid Films 426, 85-93 (2003).
[28] F.J.G. Silva, A.P.M. Baptista, E. Pereira, V. Teixeira, Q.H. Fan, A.J.S. Fernandes, and F.M. Costa, Microwave plasma chemical vapour deposition diamond nucleation on ferrous substrates with $\mathrm{Ti}$ and $\mathrm{Cr}$ interlayers, Diamond Relat. Mater. 11, 1617-1622 (2002).

[29] S. Tamulevičius, Stress and strain in the vacuum deposited thin films, Vacuum 51, 127-39 (1998).

[30] S. Tamulevičius, L. Augulis, G. Laukaitis, and M. Žadvydas, Electronic speckle pattern interferometry for micromechanical measurements, Adv. Engrg. Mater. 4, 546-550 (2002).

[31] D.H. Chen, A.X. Wei, J.B. Xu, M.M. Wu, and S.Q. Peng, Structural and optical properties of nitrogen-containing tetrahedral amorphous carbon films, Appl. Phys. A 70, 47-51 (2000).

[32] V. Baranauskas, B.B. Li, A. Peterlevitz, M.C. Tosin, and S.F. Durrant, Nitrogen-doped diamond films, J. Appl. Phys. 85, 7455-7458 (1999).

[33] R. Prioli, S.I. Zanette, A.O. Caride, D.F. Fransceschini, and F.L. Freire, Atomic force microscopy of amorphous hydrogenated carbon-nitrogen films deposited by radio-frequency-plasma decomposition of methane-ammonia gas mixtures, J. Vac. Sci. Technol. A 14, 2351-2355 (1996).

[34] S.E. Rodil, N.A. Morrison, J. Robertson, and W.L. Milne, Nitrogen incorporation into tetrahedral hydrogenated amorphous carbon, Phys. Status Solidi A 174, 25-37 (1999).

[35] A.K.M.S. Chowdhury, M. Monclus, D.C. Cameron, J. Gilvarry, M.J. Murphy, N.P. Barradas, and M.S.J. Hashmi, The composition and bonding structure of $\mathrm{CN}_{x}$ films and their influence on the mechanical properties, Thin Solid Films 308-309, 130 (1997).

[36] M. Schreck, T. Baur, R. Fehling, M. Müller, B. Stritzker, A. Bergmaier, and G. Dollinger, Modification of diamond film growth by a negative bias voltage in microwave plasma chemical vapor deposition, Diamond Relat. Mater. 7, 293-298 (1998).

[37] M. Benlahsen, J. Henocque, K. Zellama, V. Branger, and F. Badawi, The effect of hydrogen evolution on the mechanical properties of hydrogenated amorphous carbon, Diamond Relat. Mater. 7, 769-773 (1998).

[38] Qi Hua Fan, J. Gracio, Nasar Ali, and E. Pereira, Comparison of the adhesion of diamond films deposited on different materials, Diamond Relat. Mater. 10, 797802 (2001).

[39] M.I. De Barros and L. Vandenbulcke, Plasma-assisted chemical vapor deposition process for depositing smooth diamond coatings on titanium alloys at moderate temperature, Diamond Relat. Mater. 9, 1862-1866 (2000).

[40] H.D. Klotz, R. Mach, F. Oleszak, H.E. Maneck, H. Goering, and K.W. Brzezinka, Synthesis and characterization of nanoscaled and nanostructured carbon containing materials produced by thermal plasma technology, Appl. Surf. Sci. 179, 1-7 (2001). 
[41] Q.H. Fan, A. Fernandes, and J. Gracio, Diamond coating on steel with a titanium interlayer, Diamond Relat. Mater. 7, 603-606 (1998).

[42] K.Y. Li, Z.F. Zhou, C.Y. Chan, I. Bello, C.S. Lee, and S.T. Lee, Mechanical and tribological properties of diamond-like carbon films prepared on steel by ECRCVD process, Diamond Relat. Mater. 10, 1855-1861 (2001).

[43] W. Zhaocu, Y. Yuehui, and L. Xianghuai, Characteristics of carbon nitride films synthesized by ion beam enhanced deposition system, Appl. Phys. Lett. 68, 12911293 (1996).

[44] J.S. Wang, Y. Sugimura, A.G. Evans, and W.K. Tredway, The mechanical performance of DLC films on steel substrates, Thin Solid Films 325, 163-174 (1998).

[45] M.S. Wong, R. Meilumas, T.P. Ong, and R.P.H. Chang, Tribological properties of diamond films grown by plasma-enhanced chemical vapor deposition, Appl. Phys. Lett. 54, 2006-2008 (1989).
[46] Y. Jun, J.-Y. Choi, K.-R. Lee, B.-K. Jeong,S.-K. Kwon, and C.-H. Hwang, Application of diamond-like carbon films to spacer tools for electron guns of cathode ray tube CRT, Thin Solid Films 377-378, 233-238 (2000).

[47] P.J. Wilbur and D.M. Weishaar, Effects of ion beam processing parameters on the adherence of DLC films, Diamond Relat. Mater. 8, 1648-1653 (1999).

[48] F.E. Kennedy, D. Lidhagen, A. Erdemir, J.B. Woodford, and T. Kato, Tribological behavior of hard carbon coatings on steel substrates, Wear 255, 854-858 (2003).

[49] N. Yamauchi, A. Okamoto, H. Tukahara, K. Demizu, N. Ueda, T. Sone, and Y. Hirose, Friction and wear of DLC films on 304 austenitic stainless steel in corrosive solutions, Surf. Coating Technol. 174-175, 465469 (2003).

[50] T.P. Ong and R.P.H. Chang, Properties of diamond composite films grown on iron surfaces, Appl. Phys. Lett. 58, 358-360 (1991).

\title{
ANGLIES DANGU NUSODINIMAS JONU PLUOŠTELIU
}

\author{
Š. Meškinis ${ }^{a}$, S. Tamulevičius ${ }^{\text {a,b }}$, V. Kopustinskas ${ }^{b}$ \\ ${ }^{\text {a }}$ Fizikinès elektronikos institutas, Kauno technologijos universitetas, Kaunas, Lietuva \\ ${ }^{\mathrm{b}}$ Kauno technologijos universitetas, Kaunas, Lietuva
}

\section{Santrauka}

Deimanto tipo anglies dangos (DTAD) augintos ant $\mathrm{Si}(111)$ ir plieno padèklu tiesioginiu angliavandenilių (heksano, acetileno) jonų pluošteliu. Ramano sklaidos spektrai buvo panašūs i kietujjų tetraedrinių amorfinès anglies dangu spektrus. 500 ir $750 \mathrm{~K}$ temperatūroje susintezuotos polimeriškos anglies dangos. Auginimo metu angliavandenilių dujas skiedžiant azotu, užaugintos grafitiš- kesnès dangos. Kylant auginimo temperatūrai, plèvelèse stiprèjo vidiniai ittempiai. Angliavandeniliu duju skiedimas azotu taip pat silpnino vidinius ittempius. Paaiškejjo, kad deimanto tipo anglies dangos gali būti užaugintos kambario temperatūroje tiesioginiu jonų pluošteliu ant AISI 316 plieno. Veiksmingiausias DTAD sankibos su plienu sustiprinimo būdas buvo plieno paviršiaus jonpluoštis nitridavimas. 